\title{
What Insulation Material will be the New Darling of the Future Insulated Tank Containers?
}

\author{
kun Wang ${ }^{1 *}$ and Minghua $D^{2}$ \\ ${ }^{1}$ Institute of Mechanical Engineering, Nantong Vocational University, China \\ ${ }^{2}$ Nantong CIMC Tank equipment Co Itd, China
}

Submission: June 1, 2017; Published: July 17, 2017

*Corresponding author: kun Wang, Major in insulated material, storage and transportation of industrial gas, Institute of Mechanical Engineering, Nantong Vocational University, China, Email: 3383402913@qq.com

\begin{abstract}
The insulated tank containers (medium: chemical liquid, liquid food etc) normally use polyurethane(PU) and mineral wool as the insulation material, which have disadvantages such as environment-unfriendly, short applicable temperature range, and inconvenient installment etc. Researchers are trying to look for better insulation materials as the future substitution, such as nano-insulated paint, nanoaerogel, polyurethane aerogel etc.

Keywords: Insulated tank containers; Polyurethane(PU); Nano thermal insulation material; rock wool; Nano-aerogel; Polyurethane aerogel
\end{abstract}

\section{Introduction}

Every year, about 40,000 new insulated tank containers enter into the chemical logistical market, mineral wool takes $70 \%$ of the insulation material, and PU takes the left parts. Table 1 shows the main property of mineral wool and PU [1].

Table1: Present insulation material introduction for the tank container.

\begin{tabular}{|c|c|c|}
\hline Type & Mineral Wool & PU \\
\hline Temperature range $\left({ }^{\circ} \mathrm{C}\right)$ & $-20 \sim 350$ & $-20 \sim 120$ \\
\hline Installment & $\begin{array}{c}\text { Blanket, } \\
\text { Convenient, }\end{array}$ & $\begin{array}{c}\text { Panel or live foaming } \\
\text { inconvenient }\end{array}$ \\
\hline Heat conductivity $(\mathrm{W} / \mathrm{m} \bullet \mathrm{K}))$ & 0.044 & 0.026 \\
\hline Environment affect & $\begin{array}{c}\text { Irritant to the } \\
\text { skin, dust on } \\
\text { the human } \\
\text { respiratory } \\
\text { system waste } \\
\text { disposal, }\end{array}$ & $\begin{array}{c}\text { stimulus Odor } \\
\text { dust on the human } \\
\text { respiratory system } \\
\text { difficult to recycle } \\
\text { the waste }\end{array}$ \\
\hline $\begin{array}{c}\text { Unit price of insulation } \\
\text { material on 20 feet tank } \\
\text { container (RMB) }\end{array}$ & 800 & 2500 \\
\hline
\end{tabular}

Though mineral wool is cheap, but it is not environmentfriendly and its high heat conductivity can't supply the requirements of high-end customers. Unit price of PU is about 3 times of that of mineral wool, but PU's heat conductivity is about half of that of mineral wool, whereas, PU's installment is very inconvenient and not environment-friendly [2].

\section{Discussion}

For the better insulated property, convenient installment and environment-friendliness, tank manufactures and tank owners are keeping looking for much better insulation material for the future substitution, Some new-type insulation material which is used in aerospace and special fields and even still in research came into our eyesight. Table 2 shows the main property of new insulation materials (such as nano-aerogel, nano insulated paint, polyurethane aerogel) [3].

Nano-aerogel have the lowest heat conductivity, convenient installment, which have being used in the insulation of pipe and vessels though the unit price is about 9 times of that of mineral wool. Nano insulated paint with super convenient installment and wide temperature range is being used in the high-temperature vessels, though its price is about 12 times of mineral wool. Some researchers are researching new complex with PU and aerogel which can have both the advantage of PU and aerogel and higher strength [4].

The same character for Nano-aerogel, nano insulated paint, polyurethane aerogel is nano material, which have been more widely recognized and accepted by tank owners, and we believe that with more research and proper price, these nano insulated materials will be the new darling of the future insulated tank containers $[5,6]$. 


\section{Recent Advances in Petrochemical Science}

Table 2: Future insulation material application on tank containers.

\begin{tabular}{|c|c|c|c|}
\hline Type & $\begin{array}{l}\text { Nano- } \\
\text { Aerogel[1-3] }\end{array}$ & $\begin{array}{c}\text { Nano } \\
\text { Insulated } \\
\text { Paint[4-6] }\end{array}$ & $\begin{array}{c}\text { Polyurethane } \\
\text { Aerogel [7] }\end{array}$ \\
\hline $\begin{array}{l}\text { Temperature } \\
\text { range }\left({ }^{\circ} \mathrm{C}\right)\end{array}$ & $-196 \sim 600$ & $-20 \sim 1000$ & \multirow{5}{*}{$\begin{array}{c}\text { Commercial } \\
\text { products in on } \\
\text { progress. Such } \\
\text { as BASF. } \\
\text { Heat } \\
\text { conductivity } \\
\text { is estimated } \\
\text { about } \\
0.018\end{array}$} \\
\hline Installment & $\begin{array}{l}\text { Blanket, } \\
\text { Convenient }\end{array}$ & $\begin{array}{c}\text { Paint } \\
\text { convenient }\end{array}$ & \\
\hline $\begin{array}{c}\text { Heat } \\
\text { conductivity }(\mathrm{W} / \\
(\mathrm{m} \bullet \mathrm{K}))\end{array}$ & $0.016 \sim 0.018$ & $0.026 \sim 0.029$ & \\
\hline $\begin{array}{c}\text { Environment } \\
\text { affect }\end{array}$ & $\begin{array}{l}\text { Some or less } \\
\text { dust, easy to } \\
\text { recycle }\end{array}$ & $\begin{array}{c}\text { Low stimulus } \\
\text { Odor, Easy to } \\
\text { deal with the } \\
\text { waste }\end{array}$ & \\
\hline $\begin{array}{l}\text { Unit price of } \\
\text { insulation } \\
\text { material on } \\
20 \text { feet tank } \\
\text { container (RMB) }\end{array}$ & 7000 & 11000 & \\
\hline
\end{tabular}

\section{Conclusion}

Nano insulation material (such as nano-aerogel, nano insulated paint, polyurethane aerogel) will be the new darling of the future insulated tank containers. Material Price is one of the key factor for the wide application on the insulated tank containers, researcher are on the way to research insulation material with high property and proper price :

A. To gain better insulated performance, nano-aerogel is for your choice, some researcher are trying to manufacture nano-aerogel at normal pressure and temperature, instead of traditional high temperature and pressure, which will greatly decrease the material cost of nano-aerogel and improve the wide application of nano-aerogel on insulated tank containers [7].

B. To be more convenient maintenance for the insulation material, nano insulated paint is for your better choice, how to manufacture nano ceramic microspheres with low price is still difficult for the researchers.

C. To gain higher strength of the insulation material, polyurethane aerogel will be $\mathrm{OK}$ for you, we hope polyurethane aerogel will rapidly entered into commercial markets.

\section{References}

1. Huan W, Huijun W (2010) advances in the study and application of aerogels as translucent insulation materials in building energy-saving glass. Building Energy Efficiency 38(4): 35-37.

2. Wang k (2013) Application prospect of new insulation material on the cryogenic transportation equipment. vacuum and cryogenics 4: 237241.

3. jihong Z, Recent progress of polyurethane industry abroad, Proceedings of the Fifteenth Annual Conference of China Polyurethane Industry Association, pp. 97-106.

4. Zhang H, Wang F, Liang JS, Tang QG, Shang ZY, et al. (2016) Current Situation and Development Trend in Thermal Insulation Coatings, 4th Annual International conference on material science and engineering (ICMSE 2016), pp. 0340-0345.

5. Qing-Heng HE, Hui-Jun WU, Ding YF (2013) Advances of Research and Development of Transparent and Heat-insulation Coatings. Energy Conservation Technology 3: 56-60.

6. Xu Y, Li Y, Shi H, Yang Z (2010) Present Situation and Progress of Solar Heat Reflective Thermal Insulating Coatings. Paint \& Coatings Industry 40(1): 70-74.

7. https://www.basf.com

\section{Your next submission with Juniper Publishers will reach you the below assets}

- Quality Editorial service

- Swift Peer Review

- Reprints availability

- E-prints Service

- Manuscript Podcast for convenient understanding

- Global attainment for your research

- Manuscript accessibility in different formats

( Pdf, E-pub, Full Text, Audio)

- Unceasing customer service

Track the below URL for one-step submission https://juniperpublishers.com/online-submission.php 